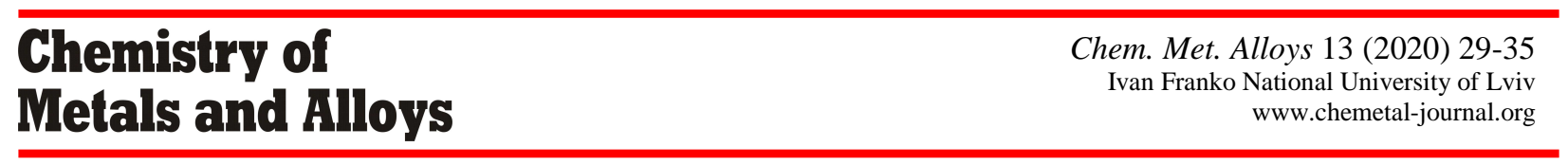

\title{
The influence of surfactants on nucleation and physico-chemical properties of lead dioxide
}

\author{
Tatiana LUK’YANENKO ${ }^{1}$, Olesia SHMYCHKOVA ${ }^{1}$, Svitlana ZAHORULKO $^{1}$, Alexander VELICHENKO $^{1}$ * \\ ${ }^{1}$ Ukrainian State University of Chemical Technology, Gagarina Ave. 8, 49005 Dnipro, Ukraine \\ * Corresponding author. Tel.: +380-56-7462825; e-mail: velichenko@ukr.net
}

Received May 25, 2020; accepted July 3, 2020; available on-line November 1, 2020

https://doi.org/10.30970/cma13.0402

The results of investigations concerning the early stages of electrocrystallization of lead dioxide from surfactant-containing media and physico-chemical properties of the composites involved are reported. The anionic surfactants were sodium laureth sulfate and sodium dodecyl sulfate. It followed from the $\mathrm{X}$-ray diffraction patterns of the $\mathrm{PbO}_{2}-\mathrm{C}_{16} \mathrm{H}_{29} \mathrm{SO}_{6} \mathrm{Na}$ samples that the surfactant additive had a significant impact on the structure of the lead dioxide. The $\beta(110)$ and $\alpha(111)$ reflections had practically disappeared, and $\beta(022)$ had appeared. In fact, the composite material is $\beta-\mathrm{PbO}_{2}$ containing an $\mathrm{X}$-ray amorphous phase of the surfactant. On the contrary, the addition of $\mathrm{C}_{12} \mathrm{H}_{25} \mathrm{SO}_{4} \mathrm{Na}$ to the nitrate electrolyte resulted in an almost twofold increase in the $\alpha$-phase content of the coating. The morphology and structure of the composite materials differed significantly from those of lead dioxide. With an increase in the surfactant content in the composite, there was a transition from large-grained deposits to materials with submicron and nano-sized crystals.

Lead(IV) oxide / Nucleation / Morphology / Phase composition

\section{Introduction}

Fabrication of new electrode materials with valuable functional properties is widely recognized to be one of the urgent tasks of modern electrochemistry [1-3]. It is necessary to have a clear understanding of both the structure of the anode material, which depends on the initial stages of the electrocrystallization, and the mechanism and kinetics of the electrochemical (and chemical) reactions taking place on it.

$\mathrm{PbO}_{2}$ is traditionally used as an anode material in applied electrochemistry due to a number of valuable benefits that allows one to use it as a platinum substitute in various processes of electrochemical synthesis [4]. The most important advantages are high electrical conductivity of the metal type, chemical resistance in aggressive solutions, the possibility to design composite materials, and ease of preparation.

Lead dioxide exists in two modifications: black, dense $(\alpha)$ and brown, highly dispersed $(\beta)$. The ratio between the amounts of the modifications formed on the electrode depends on the overvoltage of the deposition of lead dioxide and the acidity of the solution [5].

Surfactants are recognized as common additives used in the synthesis of various materials and play a significant role in changing the morphology, structure, and other physico-chemical and electrocatalytic properties of the resulting films [6]. Surfactants have shown a potential to improve the electrocatalytic activity and stability by influencing the hydrophobicity of the electrode surface $[7,8]$. Li et al. [9] reported a high decolorization rate of Acid Red G on a $\mathrm{PbO}_{2}$ electrode modified by sodium dodecyl sulfate (SDS). Similar results were obtained in our previous studies of $\mathrm{PbO}_{2}$ electrodeposited from a nitrate bath containing various surfactants and polyelectrolytes, such as sodium laureth sulfate [10], a potassium salt of nonafluorobutanesulfonic acid [11], and Nafion ${ }^{\circledR}$ [12]. Surface-active anions affect the process of electrocrystallization both through a change in the surface potential and through blocking part of the active sites on the surface [13].

Since the mechanism of anodic crystallization has a significant effect on the properties of films formed on the anode, the investigation of kinetic regularities of the crystallization process and control of its parameters are of particular interest. Herein we report data concerning the early stages of electrocrystallization of lead dioxide from surfactantcontaining media and physico-chemical properties of the composites involved. 


\section{Experimental}

All the chemicals were reagent grade. Electrodeposition regularities of doped lead(IV) oxide were studied on an Au disk electrode $\left(1 \mathrm{~cm}^{2}\right)$ by steady-state voltammetry and chronoamperometry. The electrode surface was treated, before use, by the procedure described in [14]. Such preliminary treatment permits achieving a reproducible surface. Voltammetry measurements were carried out in a standard temperature-controlled three-electrode cell. All the potentials were recorded and reported $v s$. $\mathrm{Ag} / \mathrm{AgCl} / \mathrm{KCl}_{\text {(sat.) }}$.

Electrodeposition of lead(IV) oxide was studied in methanesulfonate / nitrate electrolytes that contained $0.1 \mathrm{M} \mathrm{CH} \mathrm{CH}_{3} \mathrm{SO}_{3} \mathrm{H} / \mathrm{HNO}_{3}, 1 \mathrm{M} \mathrm{Pb}\left(\mathrm{CH}_{3} \mathrm{SO}_{3}\right)_{2}$ / $\mathrm{Pb}\left(\mathrm{NO}_{3}\right)_{2}$ and a surfactant additive, depending on the purposes of the experiments.

X-ray powder diffraction data were collected on a STOE STADI P automatic diffractometer equipped with a linear PSD detector (transmission mode, $2 \theta / \omega$ scan; $\mathrm{Cu} K \alpha_{1}$ radiation, curved germanium (1 111 ) monochromator; 2 $\theta$-range $6.000 \leq 2 \theta \leq 102.945{ }^{\circ} 2 \theta$ with a step of $0.015^{\circ} 2 \theta$; PSD step $0.480^{\circ} 2 \theta$, scan time $50 \mathrm{~s} / \mathrm{step})$.

Qualitative and quantitative phase analyses were performed using the PowderCell program [15]. For selected samples with a relatively high degree of crystallinity Rietveld refinements were carried out using the FullProf.2k (version 5.40) program [16,17].

\section{Results and discussion}

Deposition of $\mathrm{PbO}_{2}$ from various electrolytes has been the subject of a rather large number of papers [4]. The theory of nucleation and early growth of lead dioxide was proposed by Fleischmann et al. [18]. As a result of their further research $[19,20]$, a mechanism for the deposition of lead dioxide was proposed, including the nucleation of a new phase as an initial stage, instantaneous and progressive nucleation, twoand three-dimensional growth, and overlapping of growing centers. These suggestions were developed by several groups of researchers [21-23]. In particular, the formation of a hydrated form of $\mathrm{Pb}(\mathrm{IV})$ was proved by Johnson et al. [24], and later the formation of soluble intermediate oxygencontaining products of $\mathrm{Pb}(\mathrm{III})$, capable of further electrochemical transformations, was shown by Velichenko et al. [25,26].

We carried out an analysis of the mechanism of lead dioxide electrodeposition according to the following reaction scheme, described in our earlier publication [27]:

$$
\begin{aligned}
& \mathrm{H}_{2} \mathrm{O} \rightarrow \mathrm{OH}^{\cdot}{ }_{\text {ads }}+\mathrm{H}^{+}+\mathrm{e}^{-} \\
& \mathrm{Pb}^{2+}+\mathrm{OH}^{-} \text {ads } \rightarrow \mathrm{Pb}(\mathrm{OH})^{2+} \\
& \mathrm{Pb}(\mathrm{OH})^{2+}+\mathrm{H}_{2} \mathrm{O} \rightarrow \mathrm{Pb}(\mathrm{OH})_{2}{ }^{2+}+\mathrm{H}^{+}+\mathrm{e}^{-} \\
& \mathrm{Pb}(\mathrm{OH})_{2}{ }^{2+} \rightarrow \mathrm{PbO}_{2}+2 \mathrm{H}^{+}
\end{aligned}
$$

We did not see significant differences in the electrodeposition regularities during deposition from nitrate electrolytes that additionally contained surfactants. The phase composition of the coatings obtained by deposition from electrolytes containing surfactant, and not containing it, did not differ radically, therefore, we considered it possible to assume the same mechanism is involved. In our previous works, it was shown that such a mechanism is applicable to a wide range of electrolytes (both nitrate and methanesulfonate), including those containing ionic dopants [28], colloidal $\mathrm{TiO}_{2}$ [29], and polyelectrolytes [12]. As a rule, low anodic polarization $(E<1.6 \mathrm{~V})$ reactions will be under kinetic control, whereas at high polarizations the transport of $\mathrm{Pb}^{2+}$ ions to the electrode surface will be the ratedetermining stage.

Chronoamperograms were obtained on a Pt disk electrode to investigate the initial stages of deposition of lead dioxide in the presence of surfactant in the solution. The typical $j$ - $t$ curve of $\mathrm{PbO}_{2}$ deposition (not shown) could be characterized by several features and was fully consistent with the chronoamperograms obtained and described in detail by Saez et al. [30] for the deposition of lead dioxide on glassy carbon from a nitrate bath under kinetic control of process. During electrodeposition both the kinetic regularities of the crystallization process and the crystal structure of the formed oxide depend on the rate of formation of crystal nuclei, the linear crystallization rate, and their ratio. These parameters can be determined from current transients of the process of lead dioxide electrodeposition [31].

The electrocrystallization model proposed by Abyaneh [31] was selected as appropriate for the investigation of the initial stages of the formation of a new phase of lead dioxide, since it gives a more complete description and understanding of the growth mechanism of the new phase and allows one to determine the kinetic parameters of nucleation for both the $\alpha$ - and $\beta$-phases by analysis of current-time transients. According to the suggestions of Abyaneh [31], one can establish the nature of the nucleation (instantaneous or progressive) by comparing the ratio of $I_{\max }$ and $I_{\text {plat }}$. The ratio of the maximum current to the deposition current also shows the preferred geometric shape of the formed nuclei. It should be noted that a rising portion of the current transient is insensitive to the geometry of the crystal growth, which allows determining the kinetic parameters of 2D nucleation. Further formation of a crystalline deposit, when 3D nucleation is considered, and the geometry of the nuclei should be taken into account for the determination of the kinetic parameters of the formation of the new phase.

After investigation of the initial stages of $\mathrm{PbO}_{2}$ electrodeposition from nitrate electrolyte, it was established that the process proceeds by a progressive mechanism of nucleation. The preferred form of crystals at $2 \mathrm{D}$ nucleation from methanesulfonate 
Table 1 Parameters of the initial stages of lead dioxide electrocrystallization ${ }^{\text {a }}$.

\begin{tabular}{l|c|c|c|c}
\hline \multicolumn{1}{c|}{ Deposition electrolyte } & $t_{\alpha}$ & $K_{\alpha}$ & $t_{\beta}$ & $K_{\beta}$ \\
\hline $0.01 \mathrm{M} \mathrm{Pb}\left(\mathrm{NO}_{3}\right)_{2}+0.1 \mathrm{M} \mathrm{HNO}_{3}$ & 5.71 & $2.44 \times 10^{-6}$ & 6.43 & $3.95 \times 10^{-7}$ \\
$0.01 \mathrm{M} \mathrm{Pb}\left(\mathrm{NO}_{3}\right)_{2}+0.1 \mathrm{M} \mathrm{HNO}_{3}+0.0003 \mathrm{M} \mathrm{SLES}$ & 5.98 & $2.63 \times 10^{-6}$ & 7.56 & $3.84 \times 10^{-7}$ \\
$0.01 \mathrm{M} \mathrm{Pb}\left(\mathrm{NO}_{3}\right)_{2}+0.1 \mathrm{M} \mathrm{HNO}_{3}+3 \times 10^{-4} \mathrm{SDS}$ & 3.03 & $3.26 \times 10^{-6}$ & 7.87 & $1.10 \times 10^{-5}$ \\
$0.01 \mathrm{M} \mathrm{Pb}\left(\mathrm{NO}_{3}\right)_{2}+0.1 \mathrm{M} \mathrm{HNO}_{3}+7 \times 10^{-4} \mathrm{SDS}$ & 2.35 & $1.08 \times 10^{-5}$ & 6.31 & $3.30 \times 10^{-5}$ \\
$0.1 \mathrm{M} \mathrm{Pb}\left(\mathrm{CH}_{3} \mathrm{SO}_{3}\right)_{2}+1 \mathrm{M} \mathrm{CH}_{3} \mathrm{SO}_{3} \mathrm{H}+3 \times 10^{-5} \mathrm{M} \mathrm{SDS}$ & 1.51 & $6.38 \times 10^{-6}$ & 2.81 & $1.04 \times 10^{-5}$ \\
$0.1 \mathrm{M} \mathrm{Pb}\left(\mathrm{CH}_{3} \mathrm{SO}_{3}\right)_{2}+1 \mathrm{M} \mathrm{CH}_{3} \mathrm{SO}_{3} \mathrm{H}+7 \times 10^{-5} \mathrm{M} \mathrm{SDS}$ & 0.84 & $1.38 \times 10^{-6}$ & 1.08 & $8.22 \times 10^{-6}$ \\
\hline
\end{tabular}

${ }^{\mathrm{a}}$ In this table: $K_{\alpha}\left(\mathrm{mol} \mathrm{m}^{-2} \mathrm{~s}^{-1}\right)$ - rate constant for growth of $\alpha$-phase crystals in the direction perpendicular to the electrode surface; $t_{\alpha}(\mathrm{s})$ - time corresponding to the beginning of $\alpha$-phase formation; $K_{\beta}\left(\mathrm{mol} \mathrm{m}^{-2} \mathrm{~s}^{-1}\right)-$ rate constant for growth of $\beta$-phase crystals in the direction perpendicular to the electrode surface; $t_{\beta}(\mathrm{s})-$ time corresponding to the beginning of $\beta$-phase formation; SLES - sodium laureth sulfate $\left(\mathrm{C}_{16} \mathrm{H}_{29} \mathrm{SO}_{6} \mathrm{Na}\right)$; $\mathrm{SDS}$ - sodium dodecyl sulfate $\left(\mathrm{C}_{12} \mathrm{H}_{25} \mathrm{SO}_{4} \mathrm{Na}\right)$.

electrolytes is a cone [32]. The main parameters of $\mathrm{PbO}_{2}$ crystallization from nitrate solutions that additionally contain surfactant are presented in Table 1.

One can conclude from the obtained results that there are no significant changes in nucleation in the presence of surfactant. One expected effect, which we observed, is a slight deceleration due to surface inhibition by adsorbed surfactant molecules, which has also been observed in cyclic voltammograms. We did not observe qualitative differences in transients during prolonged deposition. A similar effect has been observed in the presence of polyelectrolytes and during the deposition of metals in the presence of surfactants $[10,11]$.

The data obtained here are in satisfactory agreement with the data obtained by the groups of Abyaneh and Gonzalez Garcia during the deposition of lead dioxide on glassy carbon [30,31]. The electrocrystallisation of $\mathrm{PbO}_{2}$ begins with the formation of a monolayer over the entire surface of the electrode, and only then there is formation and growth of $3 \mathrm{D}$ nuclei. The growth of lead dioxide occurs through crystallization layer by layer, so that each consequent layer is formed on a renewed surface, as has been shown in our previous work on nucleation of lead dioxide from methanesulfonate electrolytes [33].

We conducted X-ray powder diffraction in order to investigate the effect of sodium dodecyl sulfate on the phase composition of electrodeposited $\mathrm{PbO}_{2}$ and its texture. The XRPD data detected that all the investigated samples contained two phases: $\alpha-\mathrm{PbO}_{2}$ (structure type $\mathrm{Fe}_{2} \mathrm{~N}_{0.94}$, space group $\mathrm{Pbcn}$ ) and $\beta-\mathrm{PbO}_{2}$ (structure type $\mathrm{TiO}_{2}$ rutile, space group $\mathrm{P}_{2} / \mathrm{mnm}$ ). Differences were observed in the ratio of these two phases and also in the degree of crystallinity (Table 2). Typical powder patterns of modified samples are shown in Figs. 1 and 2.

As follows from the X-ray diffraction patterns of the $\mathrm{PbO}_{2}$-SLES samples, the surfactant additive has a significant impact on the structure of the lead dioxide. The reflections of the $\beta$ (110) and $\alpha$ (111) planes have practically disappeared, but $\beta$ (022) has appeared. In fact, these are composite materials containing $\beta-\mathrm{PbO}_{2}$ and a X-ray amorphous phase of the surfactant. With an increase in the content of the additive in the composite, a decrease in the intensities of almost all the reflections was observed, which probably indicates a decrease in the size of the lead dioxide crystals with increasing fraction of X-ray amorphous phases. It should be noted, however, that a decrease in the intensity of the peaks does not unambiguously indicate an increase in the amount of the crystalline phase since a similar effect on the diffractograms can also be observed when water is captured by the porous structure of lead dioxide [12]. On the contrary, the addition of SDS to the nitrate electrolyte resulted in an almost twofold increase in the $\alpha$-phase content of the coating (Table 2).

The surface of the nonmodified sample was homogeneous and large-crystalline (Fig. 3a). With a surfactant (SLES) concentration of up to $3 \%$, several zones with different surface morphologies can be distinguished (Fig. 3b): a central zone, in which there are large crystals (their size is several micrometers) and a peripheral zone, containing only small crystals of submicron size.

When the SLES content in the composite is $10 \%$, or $\mathrm{PbO}_{2}$ is doped with SDS, the surface looks more or less uniform. The surface is like a two-layer, where larger crystals of submicron size are covered by very small nano-sized crystals that have a spindle-shaped form. It should be noted that a similar morphology of coating was observed during the synthesis of $\mathrm{PbO}_{2}$ from colloidal solutions containing $\mathrm{TiO}_{2}$ [29]. A surface effect can be observed when polycrystalline blocks do not have time to form due to different adsorption rates. During the growth of large crystals, organics are adsorbed on them all the time, and gradually grow into the crystals; the zones with different areas (polycrystalline blocks and small crystals) can change during the electrolysis.

An X-ray microanalysis of the two zones was carried out. The two spectra were strictly identical. Only $\mathrm{Pb}$ and $\mathrm{O}$ were visible (very few impurities). The EDX spectra did not show an independent sulfur 
peak, probably due to the fact that its position practically coincides with the peak of lead in the oxide. For the composite containing the maximum amount of sodium laureth sulfate, a distinct carbon peak appeared on the EDX spectra. It should be noted that the maximum signal intensity was observed in areas covered by nano-sludge. However, the EDX technique allows one to measure the local content of elements on different parts of the surface and the result depends on the surface morphology. The observed picture can be the result of different specific surfaces of these areas.
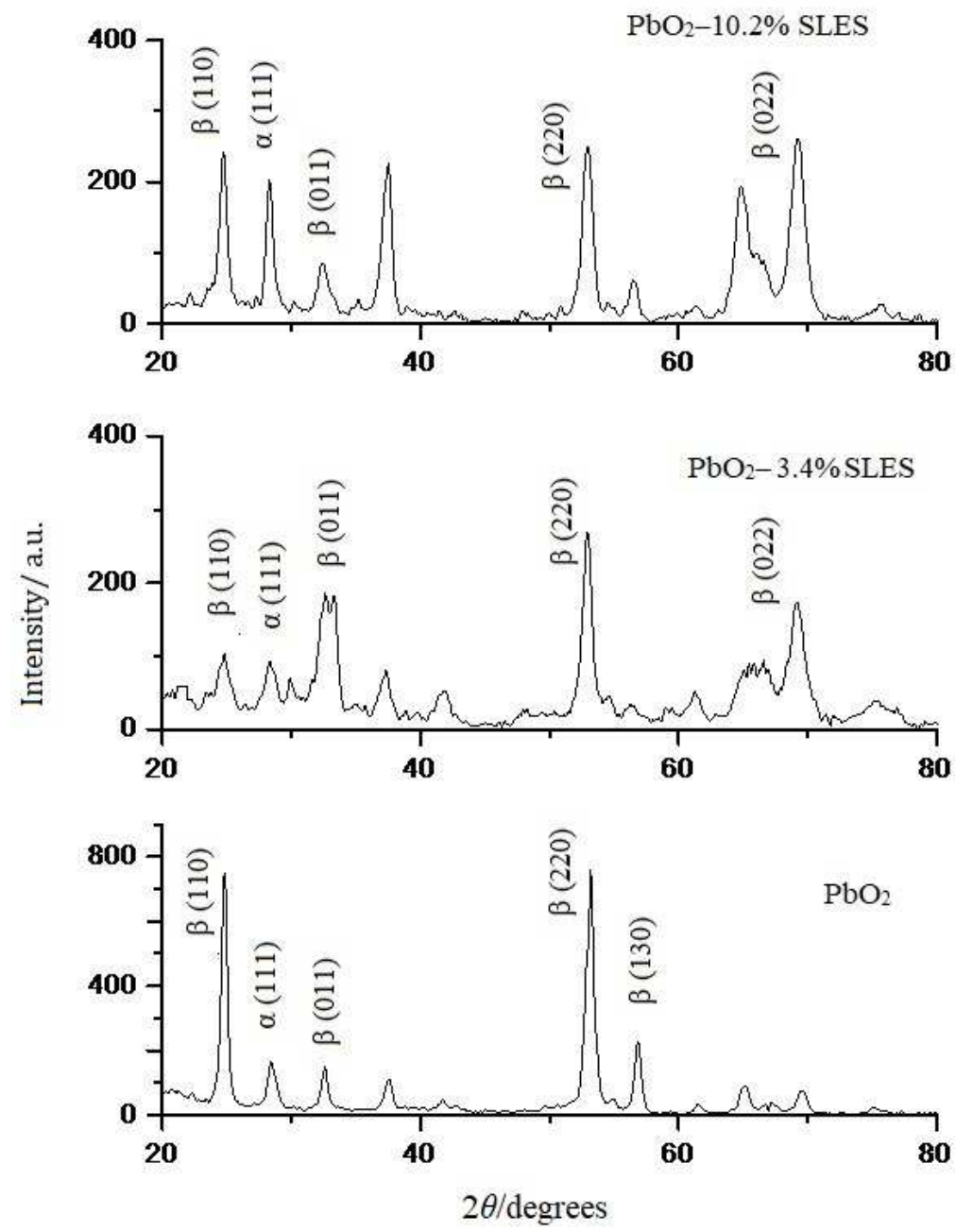

Fig. 1 X-ray diffractograms of $\mathrm{PbO}_{2}$-SLES composite materials containing 0, 3.2, and 10.2 wt.\% SLES.

Table 2 Phase composition and crystallographic data of coatings.

\begin{tabular}{|c|c|c|c|c|c|c|}
\hline \multirow{2}{*}{$\begin{array}{c}\text { Sample } \\
\text { description }\end{array}$} & \multirow{2}{*}{ Phase } & \multirow{2}{*}{$\begin{array}{l}\text { Content } \\
\text { (wt.\%) }\end{array}$} & \multicolumn{3}{|c|}{ Lattice parameters, $\AA$} & \multirow{2}{*}{$\begin{array}{c}\text { Reliability factors } \\
R_{I} / R_{\mathrm{p}}, R_{\mathrm{wp}}, R_{\text {exp }}\end{array}$} \\
\hline & & & $a$ & $b$ & $c$ & \\
\hline $0.1 \mathrm{M} \mathrm{Pb}\left(\mathrm{NO}_{3}\right)_{2}+$ & $\alpha-\mathrm{PbO}_{2}$ & $13.6(2)$ & $4.9886(10)$ & $5.9524(11)$ & $5.4600(8)$ & 0.0508 \\
\hline $1 \mathrm{M} \mathrm{HNO}_{3}$ & $\beta-\mathrm{PbO}_{2}$ & $86.4(7)$ & $4.9522(3)$ & - & $3.38217(18)$ & $\begin{array}{l}0.0200 / \\
0.0734,0.101,0.0760\end{array}$ \\
\hline $\begin{array}{l}0.1 \mathrm{M} \mathrm{Pb}\left(\mathrm{NO}_{3}\right)_{2}+ \\
1 \mathrm{M} \mathrm{HNO}_{3}+ \\
3 \times 10^{-5} \mathrm{M} \mathrm{SDS}^{-}\end{array}$ & $\begin{array}{l}\alpha-\mathrm{PbO}_{2} \\
\beta-\mathrm{PbO}_{2}\end{array}$ & $\begin{array}{l}18.6(2) \\
81.4(6)\end{array}$ & $\begin{array}{l}4.9898(8) \\
4.9563(3)\end{array}$ & $\begin{array}{l}5.9493(9) \\
-\end{array}$ & $\begin{array}{l}5.4629(7) \\
3.3840(2)\end{array}$ & $\begin{array}{l}0.0521 \\
0.0202 / \\
0.0682,0.0924,0.0678\end{array}$ \\
\hline $\begin{array}{l}0.1 \mathrm{M} \mathrm{Pb}\left(\mathrm{NO}_{3}\right)_{2}+ \\
1 \mathrm{M} \mathrm{HNO}_{3}+ \\
7 \times 10^{-4} \mathrm{M} \mathrm{SDS}^{-}\end{array}$ & $\begin{array}{l}\alpha-\mathrm{PbO}_{2} \\
\beta-\mathrm{PbO}_{2}\end{array}$ & $\begin{array}{l}26.7(2) \\
73.3(6)\end{array}$ & $\begin{array}{l}4.9921(6) \\
4.9562(3)\end{array}$ & $\begin{array}{l}5.9483(7) \\
-\end{array}$ & $\begin{array}{l}5.4625(6) \\
3.3838(2)\end{array}$ & $\begin{array}{l}0.0350 \\
0.0219 / \\
0.0699,0.0940,0.0712\end{array}$ \\
\hline
\end{tabular}




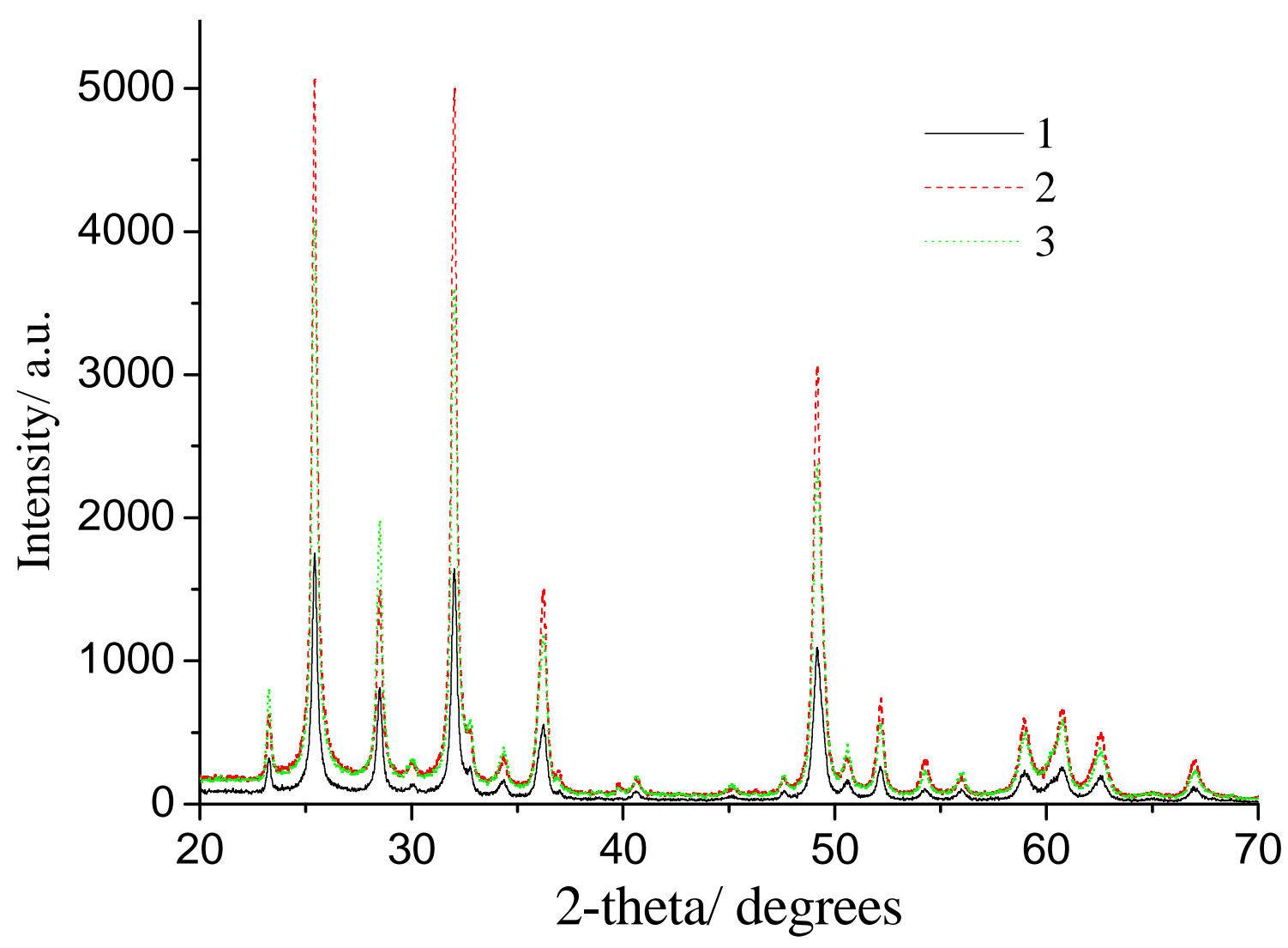

Fig. 2 XRD patterns of composite materials obtained from $1.0 \mathrm{M} \mathrm{HNO}_{3}+0.1 \mathrm{M} \mathrm{Pb}\left(\mathrm{NO}_{3}\right)_{2}+X \mathrm{M}$ SDS, where $X$ is $0(1) ; 3 \times 10^{-5}(2)$ and $7 \times 10^{-4}(3)$.

Phenolic compounds, in particular 4-chlorophenol, were selected for an estimation of the electrocatalytic activity of the composites involved in oxidation of organic compounds.

According to the literature [34], a rather large number of intermediate products are formed during the anodic oxidation of 4-chlorophenol. The main intermediate products include benzoquinone and maleic acid.

The initial solution of chlorophenol was characterized by two peaks at 220 and $280 \mathrm{~nm}$. At first, the electrolysis showed a decrease in the peak at $220 \mathrm{~nm}$, as well as a slight increase in the peak at $280 \mathrm{~nm}$ and the appearance of a plateau at 240-270 nm, which was caused by a decrease in the concentration of 4-chlorophenol and accumulation of benzoquinone in the solution. A further increase in the time of the electrolysis led to the disappearance of the peaks at 220 and $280 \mathrm{~nm}$, as well as a reduction of the plateau at $240-270 \mathrm{~nm}$, due to a decrease in the concentrations of both 4-chlorophenol and benzoquinone. Already after 4 hours of electrolysis, the aromatic compounds were completely destroyed with the formation of only aliphatic electrolysis products (mainly maleic acid), as was evidenced by
HPLC [34]. The 4-chlorophenol oxidation rate was significantly increased on the $\mathrm{PbO}_{2}$-surfactant composites. Effectively, already after 90 minutes of electrolysis, on composites that contained 2 and 4.2 wt.\% SDS, all the aromatic intermediates had been destroyed, and only aliphatic acids were found in the solution.

\section{Conclusions}

It has been revealed that there are no significant changes in the nucleation of lead dioxide in the presence of surfactant. The electrocrystallisation begins with the formation of a monolayer over the entire surface of the electrode, and only then there is formation and growth of $3 \mathrm{D}$ nuclei. The growth of lead dioxide occurs through crystallization layer by layer, so that each consequent layer is formed on a renewed surface. One expected effect, which we observed, was a slight deceleration due to surface inhibition by adsorbed surfactant molecules, which has also been observed in cyclic voltammograms. Qualitative differences in transients during prolonged deposition were not observed. 
T. Luk'yanenko et al., The influence of surfactants on nucleation and physico-chemical properties ...

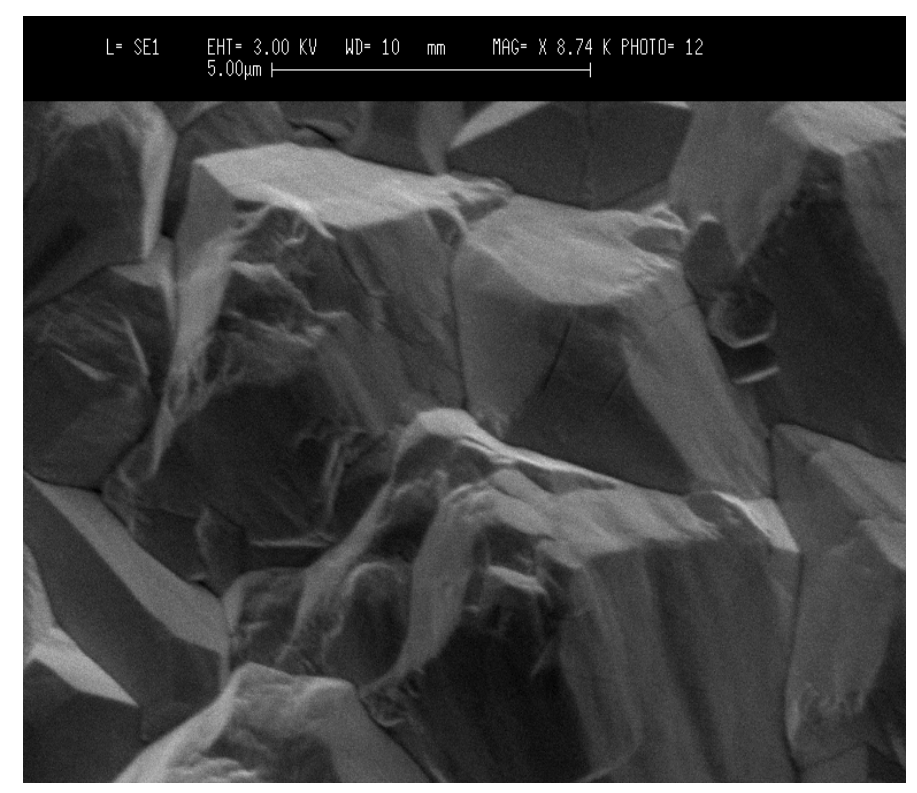

(a)

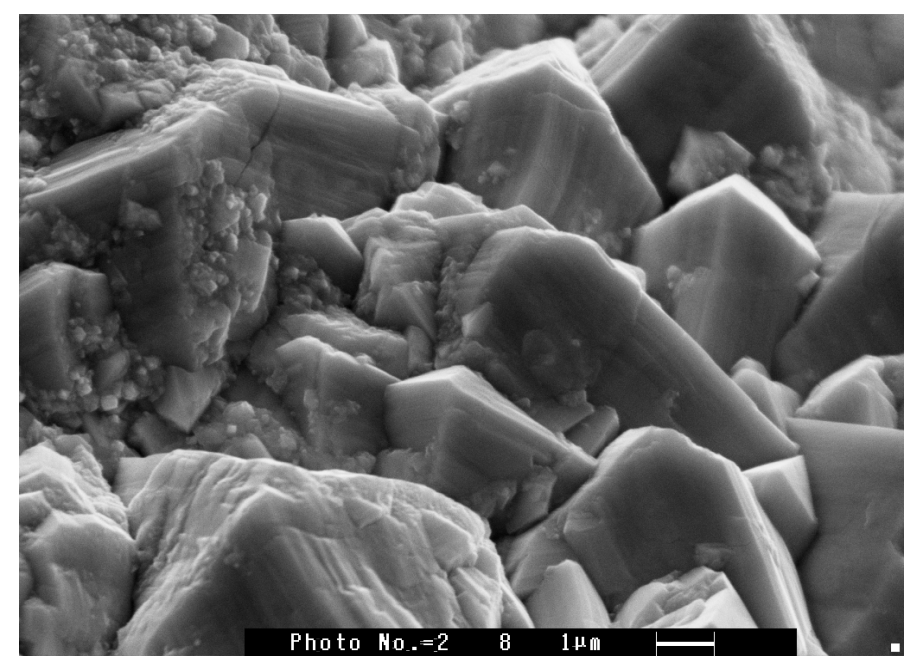

(b)

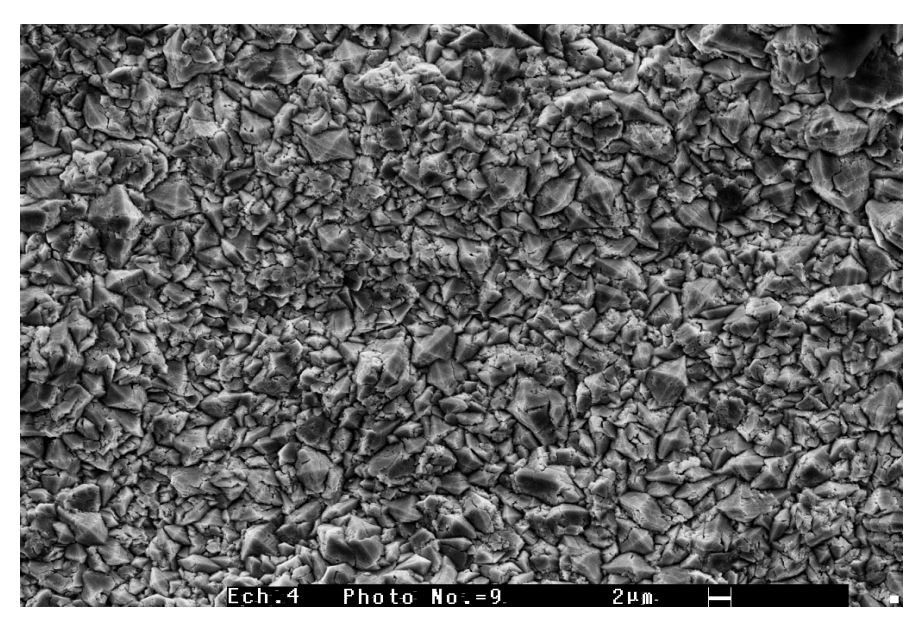

(c)

Fig. 3 SEM micrographs of nondoped $\mathrm{PbO}_{2}$ (a), $\mathrm{PbO}_{2}-3.2$ wt.\% SLES (b), and $\mathrm{PbO}_{2}-4.2$ wt.\% SDS (c). 
It follows from the X-ray diffraction patterns of the $\mathrm{PbO}_{2}$-SLES samples that the surfactant additive has a significant impact on the structure of lead dioxide. The $\beta(110)$ and $\alpha(111)$ reflections practically disappeared, but $\beta(022)$ appears. In fact, there is formation of composite materials containing $\beta-\mathrm{PbO}_{2}$ and an X-ray amorphous phase of the surfactant. On the contrary, the addition of SDS to the nitrate electrolyte resulted in an almost twofold increase in the $\alpha$-phase content of the coating. The morphology and structure of the composite materials differ significantly from those of lead dioxide. With an increase in the content of additive in the composite, there is a transition from large-grained deposits to materials with submicron and nano-sized crystals.

\section{References}

[1] F.C. Walsh, Int. J. Surf. Sci. Eng. 97(1) (2019) 28-42.

[2] F.C. Walsh, L.F. Arenas, C. Ponce de Leon, J. Chem. Technol. Biotechnol. 93(11) (2018) 3073-3090.

[3] R. Vargas, C. Borras, D. Mendez, J. Mostany, B.R. Scharifker, J. Solid State Electrochem. 20 (2016) 875-893.

[4] X. Li, D. Pletcher, F.C. Walsh, Chem. Soc. Rev. 40 (2011) 3879-3894.

[5] A.B. Velichenko, D. Devilliers, J. Fluorine Chem. 128 (2007) 269-276.

[6] B. Ameduri, Macromol. Chem. Phys. 221 (8) (2020) 1900573.

[7] T. Luk'yanenko, O. Shmychkova, L. Dmitrikova, L. Borschevich, A. Velichenko, Vopr. Khim. Khim. Tekhnol. 5 (2019) 65-70.

[8] T.V. Luk'yanenko, O.B. Shmychkova, C.V. Yanova, N.I. Krivonosova, A.B. Velichenko, J. Chem. Technol. 27(1) (2019) 92-100.

[9] X. Li, H. Xu, W. Yan, J. Alloys Compd. 718 (2017) 386-395.

[10] T. Luk'yanenko, O. Shmychkova, A. Velichenko, J. Solid State Electrochem. 24(4) (2020) 1045-1056.

[11] A. Velichenko, T. Luk'yanenko, O. Shmychkova, L. Dmitrikova, J. Chem. Technol. Biotechnol. 2020. doi: 10.1002/jctb.6483.

[12] A. Velichenko, T. Luk'yanenko, N. Nikolenko, O. Shmychkova P. Demchenko, R. Gladyshevskii, J. Electrochem. Soc. 167 (2020) 063501.

[13] C.T.J. Low, D. Pletcher, F.C. Walsh, Electrochem. Commun. 11 (2009) 1301-1304.

[14] O. Shmychkova, T. Luk'yanenko, A. Velichenko, Chem. Met. Alloys 3-4 (2016) 99-104.

[15] STOE WinXPOW, version 3.03. Darmstadt: Stoe \& Cie GmbH, 2010.
[16] W. Kraus, G. Nolze, PowderCell for Windows (version 2.4), Berlin: Federal Institute for Materials Research and Testing, 2000.

[17] J. Rodriguez-Carvajal, Recent Developments of the Program FULLPROF, Commission on Powder Diffraction (IUCr), Newsletter 26 (2001) 12-19.

[18] M. Fleischmann, M. Liler, Trans. Faraday Soc. 54 (1958) 1370-1381.

[19] M. Fleischmann, H.R. Thirsk, Electrochim. Acta 1 (1959) 146-160.

[20] M. Fleischmann, J.R. Mansfield, H.R. Thirsk, H.G.E. Wilson, W.-J. Lord, Electrochim. Acta 12 (1967) 967-982.

[21] A.T. Kuhn (Ed.), The Electrochemistry of Lead, New York: Academic Press, 1979.

[22] M.Y. Abyaneh, M. Fleischmann, E. Del Giudice, Electrochim. Acta 54 (2009) 879-887.

[23] M.Y. Abyaneh, V. Saez, J. Gonzalez-Garcia, T.J. Mason, Electrochim. Acta 55 (2010) 3572-3579.

[24] H. Chang, D.C. Johnson, J. Electrochem. Soc. 136 (1989)17-22.

[25] A.B. Velichenko, D.V. Girenko, F.I. Danilov, Electrochim. Acta 40 (1995) 2803-2807.

[26] A.B. Velichenko, D.V. Girenko, F.I. Danilov, J. Electroanal. Chem. 425(1) (1996) 127-132.

[27] A.B. Velichenko, E.A. Baranova, D.V. Girenko, R. Amadelli, S.V. Kovalyov, F.I. Danilov, Russ. J. Electrochem. 39 (2003) 615-621.

[28] A. Velichenko, O. Shmychkova, T. Luk'yanenko, R. Amadelli, Int. Conf. on Lead-Acid Batteries, LABAT, 2014, pp. $165-168$.

[29] A. Velichenko, V. Knysh O. Shmychkova, T. Luk'yanenko, Vopr. Khim. Khim. Tekhnol. 4 (2017) 14-20

[30] V. Saez, E. Marchante, M.I. Diez, M.D. Esclapez, P. Bonete, T. Lana-Villarreal, J. Gonzalez Garcia, J. Mostany, Mater. Chem. Phys. 125 (2011) 46-54.

[31] M.Y. Abyaneh, Electrocrystallization: Modeling and Its Application, in: D. Pletcher, Z-Q Tian, D. Williams (Eds.), Developments in Electrochemistry: Science Inspired by Martin Fleischmann, John Wiley \& Sons, Ltd, Chichester, UK, $2014 . \quad$ doi: 10.1002/9781118694404.ch3

[32] T. Luk'yanenko, A. Velichenko, V. Knysh, O. Shmychkova, Vopr. Khim. Khim. Tekhnol. 4 (2018) 27-35.

[33] O. Shmychkova, T. Luk'yanenko, A. Piletska, A. Velichenko, R. Gladyshevskii, P. Demchenko, R. Amadelli, J. Electroanal. Chem. 746 (2015) 57-61.

[34] O. Shmychkova, T. Luk'yanenko, L. Dmitrikova, A. Velichenko, Vopr. Khim. Khim. Tekhnol. 3 (2018) 50-57. 